\title{
食品のビタミンに及ぼす各種金属イオンの影響 \\ Influence of some Metallic Ions upon Vitamins in the Food
}

第 3 報 大根のビタミン $\mathrm{C}$ に及ぼす $\mathrm{NaCl}$ の影響

Effect of $\mathrm{NaCl}$ on the contents of Vitamin $\mathrm{C}$ in the radish.

(昭和 30 年 12 月 12 日受理)

後滕た 有 井昌子
(Tae Goto)
(Masako Arii)

ビタミンC の安定度に対する $\mathrm{NaCl}$ の影響については Marx'，一瀬氏2）等の報告があるが著者等は Roe 氏 法34516により各形態の V.C を測定し，垁駼結果は統 計処理を施して大根の身友び溶出 V.C に対する食塩の 影響を簃密に検討した。

\section{実 験 の 部}

\section{1. 実験方法}

（1）試料の調製：試料は成熟した权りま大根を用い その根部を清洗し，䇍に 4 等分しその 4 分の 1 を可及的 短時間に銀杏切り (綎1 8 就。厚さ 2 粍に切る)とし、よ く混合してそれより $10 \mathrm{~g}$ を採取した。

（2）試料の処理法：試料は生を対照として水煮沸， 食塩水劣沸（局方食塩使用）及び水浸漬，食塩水浸清を 行つたものにつき各々の緿V.C，還元型V.C 及び酸化 型V.C を測定し，それらの結果を比較してNaClのV.C に対する影響をみた。

劣沸及び浸漬の際の容量は硬質ビーカーを用い, 水及
び食㙁水は $100 \mathrm{ml}$ とし蒸溜水を使用した。

$\mathrm{NaCl}$ の敏度は調理にもつともしばしば用いる範团を とり $1 \% ， 2 \% ， 3 \%$ の 3 通りとし，堂沸及び浸清の時間 はいずれも 5 分間とし，劣沸の際は蓋を施し又大根の身 の水切りを一樣となし，同一条件のもとに 4 回測定して 平均值を出した。

なお，大根の垁踰成績の判定の一助とするために合成 1ーアスコルビン酸の溶液を劣沸水及び煮沸食塩水中に注 入して $\mathrm{NaCl}$ の影響をみた。この濃度は大根中の総V.C 含量の近似值である。

更に又酸化型 V.C に対する $\mathrm{NaCl}$ の影響も確めるた めに合成1ーアスコルビン酸溶液をブルームで完全に酸化 してジヶトグルン酸となし，その溶液について水劣沸と 食塩水煮沸とを比較した。

（3）ビタミンCの定量法：ビタミンCの定量法は2, 4-ヂニトロフェニルヒドラジンを用いるRoe氏法344)636) により実験結果は分散分析を行い処理結果の有意な篔所 に*印を附して表示した。

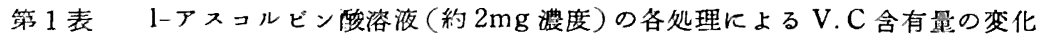
(*,**,***は $0.05,0.01,0.001$ 以下の危険率で水薏沸との差が有意である場合を示す。)

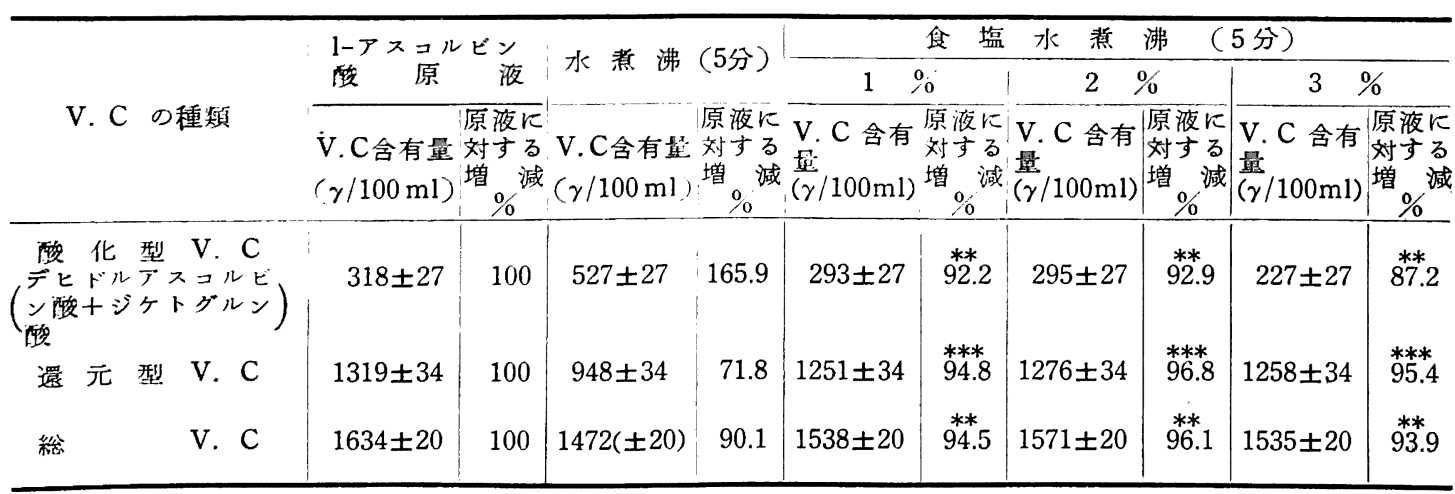




\section{栄灌を食粸}

\section{実験 結 喿}

\section{1. 合成 1-アスコルビン酸に対する食塩の影郘}

1-アスコルビン酸 $1 \mathrm{mg} / 1 \mathrm{ml}$ 溶液 $2 \mathrm{cc}$ を $100 \mathrm{ml}$ の水に

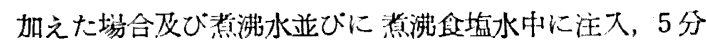
登沸の场合の变化を第 1 表に示した。

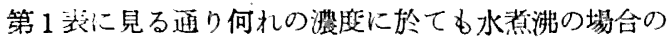
1ーアスコルビン酸の減少率約 $30 \%$ に対して食塩水省沸で

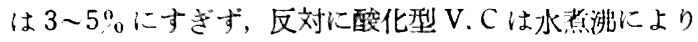
約 $66 \%$ 增加寸るのに食塩水若泥では7 13\%減少与る。 その結果総V.Cは水倠沸の场合の減少深約 $10 \%$ に対し食 塩水募沸の減少率は約4ー6\%である。

なお，食塩の1ーア、コルビン酸の減少阻止効果は各灌 度間に於ては有意の差をみとめ得られなかつた。

\section{2. 酸化型 V.C に対する令塩の影第}

上の成樍に示寸通り食塭は酸化型 V.C の減少をか之 つて促進しているのでこの事失を確めるために合成1ーア スコルビン酸溶液をブルームで完全に酸化してジヶトグ ルン酸となし，その溶液を水上食塩水で稀蚮して 1 分放 置及び 1 分煮沸を行いその变化を第 2 表に示した。

第 2 表に示寸ごとく酸化型V.Cは 1 分放置では水溶液 も食塩水溶液す何等の相違もなかつたが 1 分劣沸の場合 は食塩水溶液では水溶液より減少が大であつた。即ち食
第 2 表 变化型 V.C K対する食塩の影楆

\begin{tabular}{|c|c|c|c|c|c|c|c|c|}
\hline \multirow{2}{*}{ 处 } & \multirow{2}{*}{ 理 } & \multirow{2}{*}{ 液 } & \multicolumn{6}{|c|}{ ジケグルン酸含量 $(\gamma / 100 \mathrm{ml})$} \\
\hline & & & & 分 放 置 & & 分 & 紧 & 沸 \\
\hline \multicolumn{3}{|c|}{ 水 } & \multicolumn{2}{|r|}{2597} & \multicolumn{4}{|c|}{2299} \\
\hline $3 \%$ & 塩 & 水 & \multicolumn{2}{|r|}{2597} & \multicolumn{4}{|c|}{2179} \\
\hline
\end{tabular}

塩は堂沸に際し酸化型V.Cの破䏅を促進するものと考え られる。

\section{3. 大根の V. C. に対する食壏の影響}

A. 水及び食程水堂沸の場合の大根の V.C

大根を水港沸及び食㙁水堂沸を行つた場合の大根の身 の中のV.C，大根から溶出したV.C及びその合計の V.C について测定を行い第3 表(A)に示した。

第 3 表 (A)に示すごとく大根の身と煮汁の合部のV.C は何れの濽度の食塩水に於ても水劣沸と大差なかつたが 個々の形態のV.Cは食塩水と水とで有意の差を示した。

即ち大根の身のC と溶出したCに対する食塩の影響は 逆で身の方は還元型V.C も総V.C も食塩水ではどの清度 でも水より確央に減少が少なかつたか，これに対して㶨 汁の V.Cはいずれの篦度の食㙁水の場合も水劣沸上り遥 元型V.C も総 V.C むその減少が大であつた。

酸化型V.Cは身も汁も水と食塩水の差に有意性を示さ なかつた。

第 3 表 (A) 水煮沸及び食塩水煮沸の場合の大根及び煮汁中の V.C 含量

\begin{tabular}{|c|c|c|c|c|c|c|c|c|c|c|c|c|c|c|c|c|}
\hline \multirow{2}{*}{$\begin{array}{l}\text { 試料 } \\
\text { 番号 }\end{array}$} & \multirow{2}{*}{$\mid \begin{array}{l}\text { 募 沸 } \\
\mathrm{NaCl} \\
\text { の淺度 }\end{array}$} & \multirow{2}{*}{ V.C の種類 } & \multicolumn{2}{|c|}{$\begin{array}{l}\text { 生大根の } \\
\text { 含 有 量 }\end{array}$} & \multicolumn{4}{|c|}{ 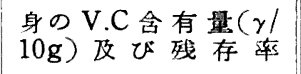 } & \multicolumn{4}{|c|}{$\begin{array}{l}\text { 汁の V.C 含有量 }(\gamma / \\
100 \mathrm{ml}) \text { 及び残存率 }\end{array}$} & \multicolumn{4}{|c|}{$\begin{array}{l}\text { 身と汁のV.C 合計含 } \\
\text { 有量 }(\gamma) \text { 及び箴高 }\end{array}$} \\
\hline & & & $\left|\begin{array}{c}10 \mathrm{~g} \text { 中の } \\
\gamma\end{array}\right|$ & $\%$ & $\left(\begin{array}{l}\text { 水者沸 } \\
(5 \text { 分) }\end{array}\right.$ & $\because 0$ & $\mid \begin{array}{c}\mathrm{NaCl} \\
\text { 水堂沸 } \\
(5 \text { 分 })\end{array}$ & $\%$ & $\mid \begin{array}{l}\text { 水竟沸 } \\
(5 \text { 分 })\end{array}$ & $\%$ & $\begin{array}{l}\mathrm{NaCl} \\
\text { 水意沸 } \\
(5 \text { 分 }\end{array}$ & $\%$ & $\begin{array}{l}\text { 水意沸 } \\
(5 \text { 分 }\end{array}$ & $\because$ & $\mid \begin{array}{c}\mathrm{NaCl} \\
\text { 水苲沸 } \\
(5 \text { 分 })\end{array}$ & $\%$ \\
\hline \multirow[t]{3}{*}{ 大根 } & \multirow{3}{*}{$1 \%$} & 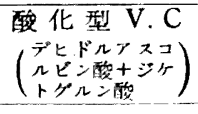 & $236 \pm 8$ & 100 & 76 & 32.3 & 74 & 31.3 & 86 & 36.4 & 96 & 40.7 & 155 & 65.7 & 163 & 69.1 \\
\hline & & 還元 型 V.C & $1878 \pm 19$ & 100 & 649 & 34.6 & $733^{*}$ & 39.0 & 946 & 50.4 & $893^{*}$ & 47.5 & 15.30 & 81.5 & 1553 & 82.7 \\
\hline & & 総 $\quad$ V. C & $2117 \pm 16$ & 100 & 725 & 32.7 & 808 & 38.2 & 1031 & 48.7 & $98 \stackrel{*}{9}$ & 46.7 & 1684 & 79.5 & 1716 & 81.1 \\
\hline \multirow[t]{3}{*}{ 大根 } & \multirow{3}{*}{$2 \%$} & 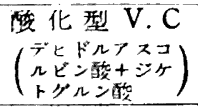 & $305 \pm 12$ & 100 & 104 & 34.1 & 127 & 41.6 & 99 & 32.5 & 91 & 29.8 & 194 & 63.6 & 205 & 67.2 \\
\hline & & 還 元 型 V. C & $1845 \pm 19$ & 110 & 718 & 36.9 & 812 & 41.7 & 1011 & 52.0 & 900 & 46.7 & 1657 & 85.2 & 1631 & 83.9 \\
\hline & & V. C & $2256 \pm 14$ & 100 & 822 & 36.4 & 940 & 41.7 & 1113 & 49.3 & $990^{*}$ & 43.9 & 1853 & 82.1 & 1836 & 81.4 \\
\hline \multirow[t]{3}{*}{ 大根 } & \multirow{3}{*}{$3 \%$} & 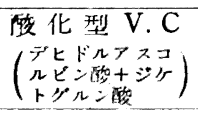 & $297 \pm 11$ & 100 & 112 & 37.7 & 119 & 40.1 & 97 & 32.7 & 108 & 36.4 & 198 & 66.7 & 215 & 72.4 \\
\hline & & 還元型 V.C & $1301 \pm 18$ & 100 & 546 & 42.0 & 578 & 44.4 & 427 & 32.8 & $338^{*}$ & 26.0 & 918 & 70.6 & 859 & 66.0 \\
\hline & & V. C & $1594 \pm 13$ & 100 & 642 & 40.2 & 697 & 43.7 & 523 & 32.8 & $444^{*}$ & $27.9 \mid$ & 1101 & 69.1 & 1071 & 67.2 \\
\hline
\end{tabular}


B. 水及び食塩水浸漬の場合の大根の V. C

大根を水漫漬及び食塩水浸清を行つた場合の大根の身 の中の V.C，大根から溶出したV.C丩ひぞの合計の V.C について定量した結果を第 3 表(B)に示した。
第 3 表(B)に示す通り大根の浸清の埸合は身汁共にい ずれの形態の V.Cに対しても影響がほとんどなく，3\% 食塩水浸清の場合の大根の還元型V.Cのみ水浸漬との差 が有意性を示して減少が少かつた。

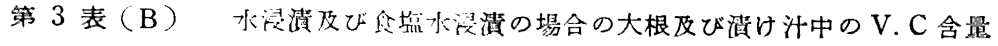

\begin{tabular}{|c|c|c|c|c|c|c|c|c|c|c|c|c|c|c|c|c|}
\hline \multirow{2}{*}{ 敌料 } & \multirow{2}{*}{$\begin{array}{l}\text { 浔 㨁 } \\
\mathrm{NaCl} \\
\text { つ灌度 }\end{array}$} & \multirow{2}{*}{ V.Cの種類 } & \multicolumn{2}{|c|}{ 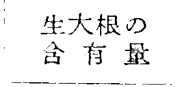 } & \multicolumn{4}{|c|}{$\begin{array}{l}\text { 身のV.C含有量 }(\gamma / \\
10 \mathrm{~g}) \text { 及 び残存率 }\end{array}$} & \multicolumn{4}{|c|}{$\begin{array}{l}\text { 汁のV.C含有量 }(\gamma / \\
100 \mathrm{ml}) \text { 及び残存率 }\end{array}$} & \multicolumn{4}{|c|}{$\begin{array}{l}\text { 身と汁のV.C合計含 } \\
\text { 有量 }(\gamma) \text { 及び残存率 }\end{array}$} \\
\hline & & & $\log _{\gamma}$ 中の & oo & 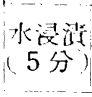 & o & $\begin{array}{l}\mathrm{NaCl} \\
\text { 水浸清 } \\
(5 \text { 分) }\end{array}$ & $\%$ & (5水浸漬 & $\%$ & $\begin{array}{l}\mathrm{NaCl} \\
\text { 水腹皘 } \\
\text { ( } 5 \text { 分) }\end{array}$ & $\%$ & $\mid \begin{array}{l}\text { 水浸鉴 } \\
(5 \text { 分 })\end{array}$ & $\%$ & 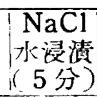 & $\%$ \\
\hline \multirow[t]{3}{*}{ 大根 } & \multirow{3}{*}{$1 \% 0$} & 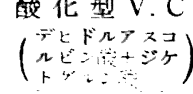 & $162 \pm 4$ & 100 & 115 & 71.0 & 116 & 71.6 & 91 & 56.1 & 85 & 52.5 & 194 & 118.8 & 189 & 116.7 \\
\hline & & 還元 型 V.C & $1061 \pm 14$ & 100 & 899 & 84.7 & 941 & 86.7 & 43 & 4.1 & 47 & 4.4 & 852 & 80.3 & 893 & 84.2 \\
\hline & & V. C & $1223 \pm 7$ & 100 & 1014 & 82.9 & 1007 & 82.3 & 133 & 10.9 & 131 & 10.7 & 1046 & 85.5 & 51037 & 84.8 \\
\hline \multirow[t]{3}{*}{ 大根 } & \multirow{3}{*}{$2 \%$} & 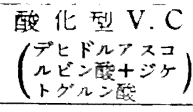 & $296 \pm 11$ & 100 & 210 & 70.9 & 182 & 61.5 & 166 & 56.1 & 153 & 51.7 & 355 & 1 LO. & 9. 317 & 107.1 \\
\hline & & 僄元型 V.C & $2323 \pm 20$ & 100 & 2015 & 86.7 & 2048 & 88.2 & 124 & 5.3 & 114 & 4.9 & 1826 & 78.6 & \begin{tabular}{|l|l|} 
& 1958 \\
\end{tabular} & 84.3 \\
\hline & & V. C & $2618 \pm 7$ & 100 & 2224 & 85.0 & 2231 & 85.2 & 290 & 11.1 & 266 & 10.2 & 2291 & 87.5 & 52249 & 85.9 \\
\hline \multirow[t]{3}{*}{ 大根 } & \multirow{3}{*}{$3 \%$} & 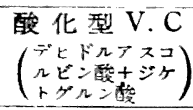 & $310 \pm 9$ & 100 & 259 & 83.3 & 239 & 77.1 & 104 & 33.5 & 92 & 29.7 & 337 & 108.7 & 307 & 99.0 \\
\hline & & 僈 元 型 V.C & $1478 \pm 12$ & 100 & 1312 & 88.8 & 1366 & 92.4 & 71 & 4.8 & 50 & 3.4 & 1252 & 84.7 & 1279 & 86.5 \\
\hline & & V. C & $1788 \pm 13$ & 100 & 1571 & 87.9 & 1604 & 89.7 & 175 & 9.8 & 142 & 7.9 & 1589 & 88.9 & 1586 & 88.7 \\
\hline
\end{tabular}

\section{結果の考案}

食塩は純粋の1ーアスコルビン酸の減少と意外に強く防 止し酸化型V.Cの含有量を相当减少してもなお総V.Cの 残存率か水浤煮より上廻つている。又第 2 表に示す通り 食塩は酸化型 V.C の破壊は促進する倾向を示す。

又侻来報告された野菜のV.Cの破壊に関する笑繢に於 ては主として供試野菜の身のCについてくわしい測定を 行つているか，液へのCの溶出か;問題となるので本垁験 では特に身と汁のCを別々に湘定してその価についてげ んみつに観察を行つた。その結果は大根の央験では身と 汁の合計の C は浸清の場合も煮洴の場合も水と食塩水と で大した差を諗められなかつた。

但し煮沸の場合は身のV.Cは還元型と総V.Cに限り食 塩水の方が水より残存率が高かつた。これに対して斗に 於ては䢱元型と総V.Cの残存率は食塩水の方が少く逆の 関係になつている。この関係は今後の研究によつて解明
したいと考えている。

終りに御指導いたたいた有山恒教授に厚く感謝の意を 表する。

\section{文献}

1) T. Marx: Ch. Abst. 45, 14 (1951).

2) 一瀬義文: 長崎大学学芸学部研究報告 (自然科学) 2 (1952); 3 (1953).

3) Paul Gyorge: Vitamin methods (II), 671-677 (1951).

4) Roe J. H., and Kuether C. A.: J. Biol. Chem. 147, 399 (1943).

5) Roe J. H., and Oesterling M. J., J. Biol. Chem. 152, 511 (1944).

6) Roe J. M., Mills M. B., Oesterling M. J., Panron C. M.: J. Biol. Chem. 174, 201 (1948).

(東北大学農学部) 